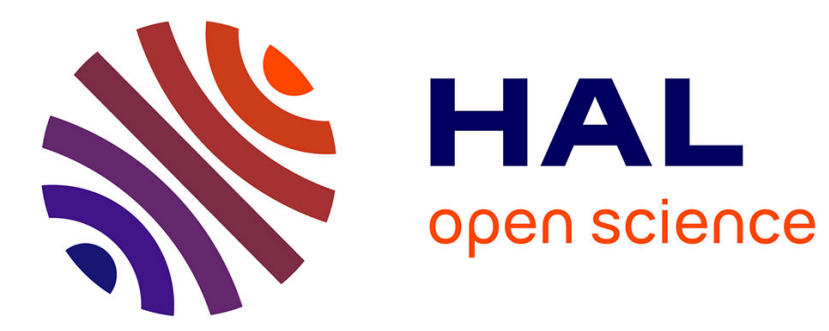

\title{
Crystal structure of base-free [MoOI4]-
}

John Gordon, Sundeep Mattamana, Rinaldo Poli, Phillip Fanwick

\section{To cite this version:}

John Gordon, Sundeep Mattamana, Rinaldo Poli, Phillip Fanwick. Crystal structure of base-free [MoOI4]-. Polyhedron, 1995, 14 (10), pp.1339-1342. 10.1016/0277-5387(94)00397-W . hal-03531317

\section{HAL Id: hal-03531317 https://hal.science/hal-03531317}

Submitted on 18 Jan 2022

HAL is a multi-disciplinary open access archive for the deposit and dissemination of scientific research documents, whether they are published or not. The documents may come from teaching and research institutions in France or abroad, or from public or private research centers.
L'archive ouverte pluridisciplinaire HAL, est destinée au dépôt et à la diffusion de documents scientifiques de niveau recherche, publiés ou non, émanant des établissements d'enseignement et de recherche français ou étrangers, des laboratoires publics ou privés. 


\title{
CRYSTAL STRUCTURE OF BASE-FREE $\left[\mathrm{MOOI}_{4}\right]^{-}$
}

\author{
JOHN C. GORDON, SUNDEEP P. MATTAMANA and RINALDO POLI* \\ Department of Chemistry and Biochemistry, University of Maryland, College Park, \\ MD 20742, U.S.A.
}

and

\section{PHILLIP E. FANWICK}

Department of Chemistry, Purdue University, West Lafayette, IN 47907, U.S.A.

(Received 26 May 1994; accepted 29 September 1994)

\begin{abstract}
Air oxidation of $\left[\mathrm{PPh}_{4}\right]_{3}\left[\mathrm{Mo}_{3} \mathrm{I}_{12}\right]$ produces $\left[\mathrm{PPh}_{4}\right]\left[\mathrm{MoOI}_{4}\right]$, a rare example of an iodide-containing molybdenum(V) complex, whose structure has been determined by $\mathrm{X}$-ray crystallography. This structural determination completes the $\left[\mathrm{MoOX}_{4}\right]^{-}(\mathrm{X}=\mathrm{Cl}$, $\mathrm{Br}$, I) series. The structural parameters are compared with those of the other halide analogues and with those of crystallographically characterized base adducts, $\left[\mathrm{MoOI}_{4}(\mathrm{~L})\right]^{-}$ $\left(\mathrm{L}=\mathrm{H}_{2} \mathrm{O}\right.$, THF). Also, a comparison between the donor power of $\mathrm{O}^{2-}$ vs the pentamethylcyclopentadienyl anion for molybdenum(V) is made possible by comparing $\left[\mathrm{MoOI}_{4}\right]^{-}$with the non-existent $\left(\eta-\mathrm{C}_{5} \mathrm{Me}_{5}\right) \mathrm{MoI}_{4}$.
\end{abstract}

Oxomolybdenum(V) derivatives are a well-investigated class of compounds, both mononuclear and dinuclear compounds being well represented. ${ }^{1}$ Most of these compounds have chloride ligands making up the valence and a smaller number of them have bromides. Rare examples of iodide-containing oxomolybdenum(V) complexes are the [Mo $\left.\mathrm{OI}_{4}(\mathrm{~L})\right]^{-}$ions $\left(\mathrm{L}=\mathrm{H}_{2} \mathrm{O}\right.$, THF $),{ }^{2}$ which may be considered as base adducts of the well-known class of oxohalide complexes [ $\left.\mathrm{MoOX}_{4}\right]^{-}$, of which both the chloro ${ }^{3}$ and bromo ${ }^{4}$ derivatives have been well characterized. The iodo member of this series has not been reported before. We report here the structure of the base-free $\left[\mathrm{MoOI}_{4}\right]^{-}$ion and discuss the structural trends of the entire $\left[\mathrm{MoOX}_{4}\right]^{-}$series, as well as the structural changes upon base coordination.

\section{EXPERIMENTAL}

$\left[\mathrm{PPh}_{4}\right]_{3}\left[\mathrm{Mo}_{3} \mathrm{I}_{12}\right]$ was prepared in situ as described elsewhere ${ }^{5}$ from $\mathrm{MoI}_{3}(\mathrm{THF})_{3}(225 \mathrm{mg}, 0.325 \mathrm{mmol})$

* Author to whom correspondence should be addressed. and $\left[\mathrm{PPh}_{4}\right] \mathrm{I}(155 \mathrm{mg}, 0.33 \mathrm{mmol})$ in $\mathrm{CH}_{2} \mathrm{Cl}_{2}(10$ $\mathrm{cm}^{3}$ ) under dinitrogen. The resulting solution was then reacted with dry air at room temperature under constant magnetic stirring. After $c a 5 \mathrm{~h}$, the purple precipitate that had formed was filtered off and dried in vacuo. Yield $156 \mathrm{mg}, 50.1 \%$. Found: C, $30.9 ; \mathrm{H}, 2.2$. Calc. for $\mathrm{C}_{24} \mathrm{H}_{20} \mathrm{I}_{4} \mathrm{MoP}: \mathrm{C}, 31.1 ; \mathrm{H}$, $2.2 \%$. IR (Nujol mull, $\left.\mathrm{cm}^{-1}\right): 970.3(\mathrm{Mo}=\mathrm{O})$. The compound is only sparingly soluble in $\mathrm{CH}_{2} \mathrm{Cl}_{2}$. Single crystals of the product were grown in two independent ways : (i) by dissolving $144 \mathrm{mg}$ of the crude product in $\mathrm{CH}_{2} \mathrm{Cl}_{2}\left(25 \mathrm{~cm}^{3}\right)$ and cooling the resulting solution to $-20^{\circ} \mathrm{C}$; (ii) by slowly diffusing air into a still solution of $\left[\mathrm{PPh}_{4}\right]_{3}\left[\mathrm{Mo}_{3} \mathrm{I}_{12}\right]$ in $\mathrm{CH}_{2} \mathrm{Cl}_{2}$. Both crystals gave the same unit cell parameters within experimental error.

A red crystal having approximate dimensions of $0.30 \times 0.28 \times 0.22 \mathrm{~mm}$ was mounted in a glass capillary in a random orientation. Cell constants and an orientation matrix for data collection were obtained from least-squares refinement, using the setting angles of 25 reflections in the range $18<\theta<22^{\circ}$, measured by the computer-controlled diagonal slit method of centring. As a measure of crystal quality, omega scans of several intense reflections were mea- 
sured; the width at half-height was $1.01^{\circ}$ with a take-off angle of $3.0^{\circ}$, indicating poor crystal quality. From the systematic absences in the $h k 0$ layer of $h+k \neq 2 n$ and from subsequent least-squares refinement, the space group was determined to be $P 4 / n$ (No. 85). Periodic monitoring of three stan-

Table 1. Crystal data for the compound $\left[\mathrm{PPh}_{4}\right]\left[\mathrm{MoOI}_{4}\right]$

\begin{tabular}{ll}
\hline Formula & $\mathrm{C}_{24} \mathrm{H}_{20} \mathrm{I}_{4} \mathrm{MoOP}$ \\
Formula weight & 958.96 \\
Space group & $P 4 / n$ \\
$a(\AA)$ & $13.205(2)$ \\
$c(\AA)$ & $8.102(2)$ \\
$V\left(\AA^{3}\right)$ & $1412.7(8)$ \\
$Z$ & 2 \\
$D_{\text {calc }}\left(\mathrm{g} \mathrm{cm}^{-3}\right)$ & 2.254 \\
$\mu\left(\right.$ Mo- $\left.K_{\alpha}\right)\left(\mathrm{cm}^{-1}\right)$ & 48.50 \\
Radiation $($ wavelength) & Mo- $K_{\alpha}$ \\
& $(\lambda=0.71073 \AA)$ \\
Monochromator & graphite \\
Temp. $\left({ }^{\circ} \mathrm{C}\right)$ & 20 \\
Transmission factors : max, min & $1.000,0.535$ \\
Diffractometer & Enraf-Nonius \\
& $\mathrm{CAD} 4$ \\
Scan method & $\omega-2 \theta$ \\
$h, k, l$ limits & $0-15,0-15,0-9$ \\
$2 \theta$ range ( $\left.{ }^{\circ}\right)$ & $4.00-50.00$ \\
$F(000)$ & 882.0 \\
$p$-factor used in weighting & 0.040 \\
Data collected & 1466 \\
Unique data & 1368 \\
Agreement factor (on $I)$ & 0.033 \\
Data with $I>3.0 \sigma(I)$ & 992 \\
Number of variables & 72 \\
Largest shift/e.s.d. in final cycle & 0.06 \\
$R^{a}$ & 0.054 \\
$R_{\mathrm{w}}{ }^{b}$ & 0.076 \\
Goodness of fit & 2.542 \\
& \\
\hline & \\
\hline & \\
&
\end{tabular}

${ }^{a} R=\Sigma\left\|F_{\mathrm{o}}|-| F_{\mathrm{c}}\right\| / \Sigma\left|F_{\mathrm{o}}\right|$.

${ }^{b} R_{\mathrm{w}}=\left[\Sigma w\left(\left|F_{\mathrm{o}}\right|-\left|F_{\mathrm{c}}\right|\right)^{2} / \Sigma w\left|F_{\mathrm{o}}\right|^{2}\right]^{1 / 2} ; w=1 / \sigma^{2}\left(\left|F_{\mathrm{o}}\right|\right)$. dard reflections did not show a significant variation in intensity, thus a decay correction was not applied. Lorentz and polarization correction were applied to the data, and an empirical absorption correction based on the method of Walker and Stuart was also applied. ${ }^{6}$ Intensities of equivalent reflections were averaged. Sixty-four reflections were rejected from the averaging process because their intensities differed significantly from the average. The agreement factors for the averaging of the 22 observed and accepted reflections was 3.3\% based on intensity and $2.4 \%$ based on $F_{0}$.

The structure was solved using the structure solution program SHELXS-86. ${ }^{7}$ The remaining atoms were located in succeeding difference Fourier syntheses. Hydrogen atoms were located and added to the structure factor calculations but their positions were not refined. Crystal data are collected in Table 1 and selected bond distance and angles are reported in Table 2 in comparison with those of other $\left[\mathrm{MoOX}_{4}\right]^{-}$ions and with those of $[\mathrm{Mo}$ $\left.\mathrm{OI}_{4}(\mathrm{~L})\right]^{-}\left(\mathrm{L}=\mathrm{H}_{2} \mathrm{O}, \mathrm{THF}\right)$.

The atomic coordinates have been deposited with the Cambridge Crystallographic Data Centre.

\section{RESULTS AND DISCUSSION}

The title compound forms as a purple microcrystalline solid by air oxidation of the trinuclear face-shared trioctahedral $\left[\mathrm{Mo}_{3} \mathrm{I}_{12}\right]^{3-}$ species ${ }^{5}$ in dry $\mathrm{CH}_{2} \mathrm{Cl}_{2}$. The reaction formally entails the addition of an oxygen atom to each molybdenum centre in the trinuclear anion which is fragmented into mononuclear species. The compound shows the characteristic $\mathrm{Mo}=\mathrm{O}$ stretching vibration at 970 $\mathrm{cm}^{-1}$, which is to be compared with $1005 \mathrm{~cm}^{-1}$ for $\left[\mathrm{MoOBr}_{4}\right]^{-4}$ and $1015 \mathrm{~cm}^{-1}$ for $\left[\mathrm{MoOCl}_{4}\right]^{-3 \mathrm{e}}$ This trend correlates with the decreased electronegativity on going from chlorine to bromine to iodine. Prolonged exposure to air of solutions and

Table 2. Comparison of selected bond distances $(\AA)$ and angles $\left({ }^{\circ}\right)$ for $\left[\mathrm{MoOX}_{4}\right]^{-}(\mathrm{X}=\mathrm{Cl}, \mathrm{Br}, \mathrm{I})$ and $\left[\mathrm{MoOI}_{4}(\mathrm{~L})\right]^{-}$ $\left(\mathrm{L}=\mathrm{H}_{2} \mathrm{O}\right.$, THF) ions

\begin{tabular}{lccccc}
\hline Ion $^{a}$ & Mo-X $(\AA)$ & $\mathrm{Mo}-\mathrm{O}(\AA)$ & $\mathrm{X}-\mathrm{Mo}-\mathrm{X}\left({ }^{\circ}\right)$ & $\mathrm{X}-\mathrm{Mo}-\mathrm{X}^{\prime}\left({ }^{\circ}\right)$ & $\mathrm{X}-\mathrm{Mo}-\mathrm{O}\left({ }^{\circ}\right)$ \\
\hline$\left[\mathrm{MoOI}_{4}\right]^{-}$ & $2.713(1)$ & $1.61(2)$ & $151.4(1)$ & $86.50(2)$ & $104.30(5)$ \\
{$\left[\mathrm{MoOBr}_{4}\right]^{-}$} & $2.469(1)$ & $1.73(1)$ & $156.0(1)$ & $87.5(0)$ & $102.0(1)$ \\
{$\left[\mathrm{MoOCl}_{4}\right]^{-}$} & $2.333(3)$ & $1.61(1)$ & $149.5(1)$ & $86.0(1)$ & $105.2(1)$ \\
& $2.324(7)$ & $1.71(3)$ & $150.8(2)$ & $86.4(1)$ & $104.6(2)$ \\
$\left.\mathrm{MoOI}_{4}\left(\mathrm{H}_{2} \mathrm{O}\right)\right]^{-}$ & $2.76(1)$ & $1.65(1)$ & $164.4(1)$ & $88.9(4)$ & $97.8(3)$ \\
{$\left[\mathrm{MoOI}_{4}(\mathrm{THF})\right]^{-}$} & $2.75(2)$ & $1.64(1)$ & $168(3)$ & $89(2)$ & $96(2)$ \\
\hline
\end{tabular}

${ }^{a}\left[\mathrm{PPh}_{4}\right]\left[\mathrm{MoOI}_{4}\right]:$ this work ; $\left[\mathrm{PPh}_{4}\right]\left[\mathrm{MoOBr}_{4}\right]:$ ref. $4 ;\left[\mathrm{AsPh}_{4}\right]\left[\mathrm{MoOCl}_{4}\right]$ : results of two independent determinations reported in ref. 3a (above) and $3 \mathrm{~b}$ (below); $\left[\mathrm{NEt}_{4}\right]\left[\mathrm{MoOI}_{4}\left(\mathrm{H}_{2} \mathrm{O}\right)\right]$ : average values from ref. $2 \mathrm{a} ;\left[\mathrm{Mo}_{2} \mathrm{I}_{3} \mathrm{O}\left(\mathrm{O}_{2}\right.\right.$ $\left.\left.\mathrm{CCH}_{3}\right)(\mathrm{THF})_{4}\right]\left[\mathrm{MoOI}_{4}(\mathrm{THF})\right]$ : average values from ref. $2 \mathrm{~b}$. 
suspensions of the purple $\left[\mathrm{MoOI}_{4}\right]^{-}$salt yields a brown insoluble material which also shows a strong $\mathrm{Mo}=\mathrm{O}$ stretch in the IR spectrum at $970 \mathrm{~cm}^{-1}$. This decomposition product has a much lower carbon, hydrogen analysis, indicating a $\mathrm{PPh}_{4}^{+}$salt of an oligonuclear Mo- $-\mathrm{O}-\mathrm{I}$ anion, but the material has not been further characterized.

$\left[\mathrm{PPh}_{4}\right]\left[\mathrm{MoOI}_{4}\right]$ crystallizes in the tetragonal space group $P 4 / n$ with the cation located on a $\overline{4}$ site and the anion on a 4 site. The structure is isomorphous with those reported previously for the $\left[\mathrm{AsPh}_{4}\right]\left[\mathrm{MoOCl}_{4}\right]^{3 \mathrm{a}, \mathrm{b}}$ and $\left[\mathrm{PPh}_{4}\right]\left[\mathrm{MoOBr}_{4}\right]^{4}$ salts. The cation is unexceptional and will not be discussed further. A view of the anion is shown in Fig. 1 and the bond distances and angles are collected in Table 2 and compared with those of the analogous $\left[\mathrm{MoOX}_{4}\right]^{-}(\mathrm{X}=\mathrm{Cl}, \mathrm{Br})$ ions and with those of the base adducts $\left[\mathrm{MoOI}_{4}(\mathrm{~L})\right]^{-}\left(\mathrm{L}=\mathrm{H}_{2} \mathrm{O}\right.$, THF $)$. As for the analogous $\left[\mathrm{MoOX}_{4}\right]^{-}(\mathrm{X}=\mathrm{Cl}, \mathrm{Br})$ ions, the geometry can be described as a square pyramid with the oxo ligand occupying the apical position and the four iodides identifying the square base. The geometry of the base adducts, on the other hand, is pseudo-octahedral with the neutral base located trans with respect to the oxo ligand. Thus, coordination of the base perturbs only slightly the geometry of the base-free anion.

The Mo-I distance for the title compound is near the short end of the reported range for such a parameter, being slightly shorter than the Mo-I bonds in the cationic molybdenum(IV) complex $\left[\mathrm{CpMoI}\left(\mathrm{PMe}_{3}\right)_{2}\right]^{+}$, e.g. 2.721(2) and 2.742(2) $\AA{ }^{8}{ }^{8}$ but slightly longer than the terminal Mo-I distance reported for the class of $\mathrm{Mo}_{3} \mathrm{HI}_{7} \mathrm{~L}_{3}$ clusters $[\mathrm{L}=\mathrm{THF}, 2.688(3)$ and 2.692(4) $\AA$; $\mathrm{MeCN}$, 2.710(5) $\AA ; \mathrm{PhCN}, 2.673(4) \AA]$. ${ }^{9}$ In comparison with the $\left[\mathrm{MoOI}_{4}\left(\mathrm{H}_{2} \mathrm{O}\right)\right]^{-}$and $\left[\mathrm{MoOI}_{4}(\mathrm{THF})\right]^{-}$ structures (see Table 2), the Mo-I distance is shorter by $c a 0.04 \AA$. The lengthening upon coordination of the axial base is expected as a result of a greater electron density on the metal centre. For the chloro and bromo systems, the Mo- $\mathrm{X}$ lengths experience an analogous lengthening as a result

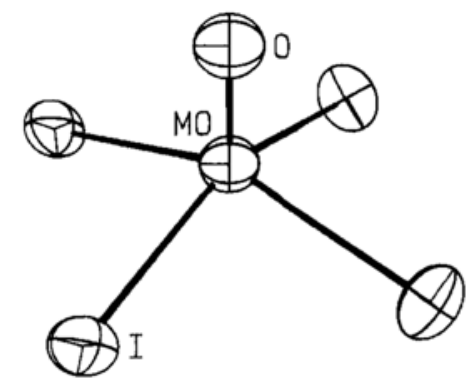

Fig. 1. An ORTEP view of the $\left[\mathrm{MoOI}_{4}\right]^{-}$ion. of base coordination $\{0.04 \AA$ on going from $\left[\mathrm{MoOCl}_{4}\right]^{-}$to $\left[\mathrm{MoOCl}_{4}\left(\mathrm{H}_{2} \mathrm{O}\right)\right]^{-,},{ }^{10}$ and $0.05 \AA$ on going from $\left[\mathrm{MoOBr}_{4}\right]^{-}$to $\left[\mathrm{MoOBr}_{4}\left(\mathrm{H}_{2} \mathrm{O}\right)^{-}\right\} .^{2 a}$ For the same reason, the $\mathrm{Mo}=\mathrm{O}$ distance is significantly shorter in the base-free complex. The introduction of an axial base causes an expected opening of the $\mathrm{MoI}_{4}$ umbrella, with the $\mathrm{O}=\mathrm{Mo}-\mathrm{I}$ angles being $6-8^{\circ}$ larger and the trans-I-Mo-I correspondingly $12-16^{\circ}$ smaller in the base-free complex (see Table 2).

A comparison between the structural parameters of the different $\left[\mathrm{MoOX}_{4}\right]^{-}$ions is rather interesting. There are unexpected discrepancies between the Mo-O distances in different ions (see Table 2) and even between two separate structural determinations for the same compound, i.e. [As $\left.\mathrm{Ph}_{4}\right]\left[\mathrm{MoOCl}_{4}\right]$ (the two crystals being isomorphous but with significantly different volumes). For the two different $\left[\mathrm{MoOCl}_{4}\right]^{-}$determinations, ${ }^{3 \mathrm{a}, \mathrm{b}}$ the Mo-O distance varies by as much as $0.1 \AA$, the other parameters varying to a much lesser extent. Concerning the other two ions, $\left[\mathrm{MoOBr}_{4}\right]^{-}$ shows a long $\mathrm{Mo}-\mathrm{O}$ distance, similar to that of the $\left[\mathrm{MoOCl}_{4}\right]^{-}$ion with the longer $\mathrm{Mo}-\mathrm{O}$ bond, and also quite different angular parameters corresponding to a flatter $\mathrm{MoBr}_{4}$ plane. The Mo-O distance in $\left[\mathrm{MoOI}_{4}\right]^{-}$, on the other hand, is close to that of the $\left[\mathrm{MoOCl}_{4}\right]^{-}$ion with the shorter $\mathrm{Mo}-\mathrm{O}$ bond, and the other geometric parameters compare quite well with those of both determinations of the chloro species. It is not clear what may cause such an unexpected variation in geometric parameters. An artificially longer Mo- $\mathrm{O}$ bond could result from compositional disorder with a co-crystallized impurity such as a square pyramidal $\left[\mathrm{MoX}_{5}\right]^{-}$ion, although the existence of such a species seems doubtful. ${ }^{11}$ The Mo—O distances around $1.7 \AA$ do not appear reasonable, because a lengthening of this distance is expected upon coordination of an axial base, and the Mo- $\mathrm{O}$ distances in trans$\left[\mathrm{MoOX}_{4}\left(\mathrm{H}_{2} \mathrm{O}\right)\right]^{-}$are $1.66(1){ }^{10} \quad 1.65(1)^{2 \mathrm{a}}$ and 1.65(1) $\AA^{2 \mathrm{a}}$ for $\mathrm{X}=\mathrm{Cl}, \mathrm{Br}$ and $\mathrm{I}$, respectively, i.e. more in accord with the distances around $1.6 \AA$ for $\mathrm{Mo}-\mathrm{O}$ in the base-free $\left[\mathrm{MoOX}_{4}\right]^{-}$ions. Other relevant $\mathrm{Mo}-\mathrm{O}$ distances are 1.641(4) $\AA$ in $\left[\mathrm{Me}_{2} \mathrm{C}=\mathrm{NH}_{2}\right]\left[\mathrm{MoOCl}_{4}\right]$, where the anions are arranged pairwise to yield weak axial $\mathrm{O}=\mathrm{Mo} \cdots \mathrm{Cl}$ interactions, ${ }^{3 \mathrm{~d}}$ and $1.65(1) \quad \AA$ in $\left[\mathrm{AsPh}_{4}\right]_{2}$ $\left[\mathrm{MoOCl}_{4}\right]\left[\mathrm{MoOCl}_{4}(\mathrm{MeCN})\right]$ (same distance found in the base-free ion and in its acetonitrile adduct) ${ }^{3 \mathrm{c}}$

Finally, we would like to remark that the $\left[\mathrm{MoOI}_{4}\right]^{-}$ion and its base adducts are rare examples of iodide-containing molybdenum(V) species. Iodide is usually not compatible with high oxidation state metals because it can be easily oxidized by them to afford polyiodide salts of the metal 


\section{J. C. GORDON et al.}

in a lower oxidation state through an internal redox process. Thus, although chloride and bromide support the oxidation states $\mathrm{V}$ and $\mathrm{IV}$ for molybdenum in $\mathrm{MoCl}_{5}$ and $\mathrm{MoBr}_{4}$, respectively, the highest oxidation state homoleptic molybdenum iodide known is $\mathrm{MoI}_{3} \cdot{ }^{12} \mathrm{~A}$ way to render the metal less oxidizing is to increase its electron density through donation from the ligand system. Oxygen is a very strong $\pi$ donor and serves well for this purpose. It is interesting to make a comparison between $\left[\mathrm{MoOI}_{4}\right]^{-}$ and another system recently reported by us, namely $\left[\mathrm{Cp} * \mathrm{MoI}_{4}\right]^{-}$, which shows an identical square pyramidal coordination geometry with the $\mathrm{Cp}^{*}$ ligand in the apical position. ${ }^{13}$ The latter is a molybdenum(IV) complex, and a cyclic voltammetric investigation was carried out to probe for the possible oxidation to a neutral $\mathrm{Cp} * \mathrm{MoI}_{4}$ complex of molybdenum(V). It was found, however, that the first observed oxidation process involves the $\mathrm{I}^{-}$ligands to afford $\mathrm{I}_{3}^{-}$, thereby proving the internal redox instability of a hypothetical neutral Cp* $\mathrm{MoI}_{4}$ complex of molybdenum(V). It is pertinent to mention here that the corresponding $\left[\mathrm{Cp}^{*} \mathrm{MoX}_{4}\right]^{-}(\mathrm{X}=\mathrm{Cl}, \mathrm{Br})$ undergo reversible electrochemical oxidations to the corresponding square pyramidal neutral complexes of molybdenum(V), which are stable and isolable species. ${ }^{13}$ Therefore, the molybdenum centre is less oxidizing (electron richer) in $\left[\mathrm{MoOI}_{4}\right]^{-}$(I) than in $\mathrm{Cp}^{*} \mathrm{MoI}_{4}$ (II), meaning that $\mathrm{O}^{2-}$ is overall a stronger electron donor than $\mathrm{Cp}^{*-}$ for molybdenum(V). We point out here that the oxo ligand, when it can make use of both lone pairs for $\pi$-bonding, is a six-electron donor just like $\mathrm{Cp}^{*--}$, justifying the formalism used in structures I and II.

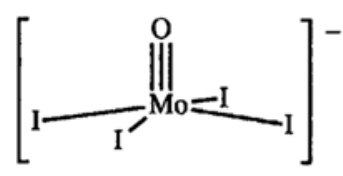

I

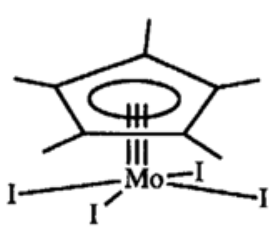

II
Acknowledgements - We thank the National Science Foundation and the Alfred P. Sloan Foundation for support of this research through awards (PYI and Research Fellowship, respectively) to R.P.

\section{REFERENCES}

1. G. Wilkinson, R. D. Gillard and J. A. McCleverty (Eds), Comprehensive Coordination Chemistry, Vol. 3. Pergamon, Oxford (1987).

2. (a) A. Bino and F. A. Cotton, Inorg. Chem. 1979, 18, 2710 ; (b) F. A. Cotton and R. Poli, Polyhedron 1987, 6, 2181.

3. (a) C. D. Garner, L. H. Hill, F. E. Mabbs, D. L. McFadden and A. T. McPhail, J. Chem. Soc., Dalton Trans. 1977, 853 ; (b) B. Knopp, K.-P. Lörcher and J. Strähle, Z. Naturfor. 1977, 32b, 1361 ; (c) F. Weller, U. Müller, U. Weiher and K. Dehnicke, Z. Anorg. Allg. Chem. 1980, 460, 191 ; (d) P. Klinzing, A. ElKholi, U. Müller, K. Dehnicke and K. Findeisen, $Z$. Anorg. Allg. Chem. 1989, 569, 83; (e) P. M. Boorman, C. D. Garner and F. E. Mabbs, J. Chem. Soc., Dalton Trans. 1975, 1299.

4. C. Schumacher, F. Weller and K. Dehnicke, Z. Anorg. Allg. Chem. 1982, 495, 135.

5. J. C. Fettinger, S. P. Mattamana, R. Poli and G. Salem, manuscript in preparation.

6. N. Walker and D. Stuart, Acta Cryst. 1983, A39, 158.

7. G. M. Sheldrick, SHELXS-86, Institut für Anorganische Chemie der Universität Göttingen, Germany (1986).

8. R. Poli, A. L. Rheingold and B. E. Owens-Waltermire, Inorg. Chim. Acta 1993, 203, 223.

9. F. A. Cotton and R. Poli, J. Am. Chem. Soc. 1988, 110, 830 .

10. (a) C. D. Garner, L. H. Hill, F. E. Mabbs, D. L. McFadden and A. T. McPhail, J. Chem. Soc., Dalton Trans. 1977, 1202 ; (b) A. Bino and F. A. Cotton, J. Am. Chem. Soc. 1979, 101, 4150.

11. There is only a sporadic report of an incompletely characterized $\mathrm{Li}\left[\mathrm{MoCl}_{5}\right]$ compound: $\mathrm{K}$. Jacob and K.-H. Thiele, Z. Anorg. Allg. Chem. 1984, 508, 50.

12. F. A. Cotton and G. Wilkinson, Advanced Inorganic Chemistry, 5th edn. John Wiley, New York (1988).

13. J. U. Desai, J. C. Gordon, H.-B. Kraatz, V. T. Lee, B. E. Owens-Waltermire, R. Poli, A. L. Rheingold and C. B. White, Inorg. Chem. 1994, 33, 3752. 